Tales of Ise 



\section{Tales of Ise}

\section{Lyrical Episodes from Tenth-Century Japan}

Translated, with an Introduction and Notes, by

HELEN CRAIG MCCULLOUGH

Stanford University Press

Stanford, California 
Stanford University Press

Stanford, Californı

(C) 1968 by the Board of Trustees of the

Leland Stanford Junıor University

ISBN 0-8047-0653-0

Original printıng 1968

Last figure below indicates year of this printing.

$\begin{array}{llllllllll}08 & 07 & 06 & 05 & 04 & 03 & 02 & 01 & 00 & 99\end{array}$

This book is printed on acid-free paper 
For Bill 
